\title{
The Past and Future of Canadian Generalist Law Journals
}

\author{
BRUCE RYDER
}

TABLE OF CONTENTS

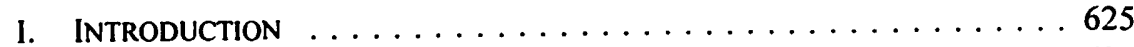

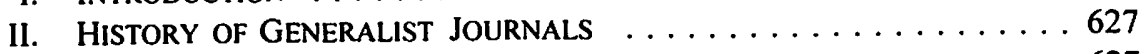

A. EARliest ENTRANTS . . . . . . . . . . . . . . 627

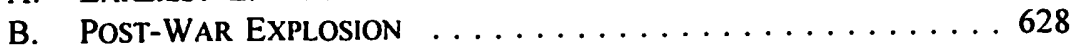

III. WHY UNIVERSITY-BASED GENERALIST JOURNALS? . . . . . . . . 630

A. INITIAL INTENTIONS . . . . . . . . . . . . . 630

B. Change In Function . . . . . . . . . . . . . . 631

IV. THE EMERGENCE OF SPECIALIST JOURNALS . . . . . . . . . . . 632

V. WHY RETAIN A GENERALIST FORMAT? . . . . . . . . . . . 635

VI. CONCLUSION ....................... 636

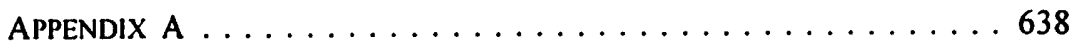

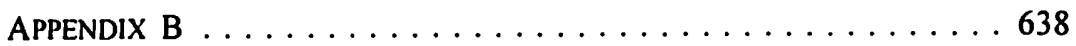

\section{INTRODUCTION}

There is almost a complete absence of published scholarship about scholarly legal periodicals in Canada. We have been building an impressive structure brick by brick for many years, but without any apparent overall design, and we have not stepped back to examine the coherence of the net result. There are a few published articles that chronicle the history of particular Canadian law journals.' Scholars have made valuable contributions to our understanding of the important role played by periodicals and other forms of scholarship in advancing and safeguarding civilist traditions in Quebec. ${ }^{2}$ But we are lacking published work that examines the world of Canadian law journals generally; that describes their current organizational structures, their practices and procedures, their scholarly and educational aims, their relationship to other publications, to law schools,

Associate Professor, Osgoode Hall Law School. York University; Editor-in-Chief, Osgoode Hall Law Journal, 1997-2000. This article is based on a presentation to the Symposium on the "Role and Future of the Law Review" held at the Faculty of Law, University of Alberta on 28 May 2000. 1 am grateful to the organizers for the opportunity to participate in the panel and this symposium. I would also like to thank my research assistant Tiffany Turnbull, Osgoode Hall Law School. Class of 2002, for diligently and skilfully compiling a two-volume catalogue (on file with the Osgoode Hall Law Journal) of the origins, history, and objectives of generalist and specialist law journals published in Canada.

$1 \quad$ See, e.g., J-G. Belley, "Une croisade intégriste chez les avocats du Québec: La Revue du droit (19221939)" (1993) 34 C. de D. 183; A. Smith. "The Alberta Law Quarterly: Random Reminiscences" (1980) 18 Alta. L. Rev. 38; M. MacLaren, "A History of the University of Toronto Faculty of Law" Review" (1997) 55 U.T. Fac. L. Rev. 375: R.C.B. Risk, "Volume I of the Journal: A Tribute and a Belated Review" (1987) 37 U.T.L.J. 193; G. Curtis, "Fifty Years On" (1999) 33 U.B.C. L. Rev. 1; P. Burns et al., "A Noteworthy Review" (1999) 33 U.B.C. L. Rev. 3.

2 $\quad$ See Belley, supra note 1; R.A. Macdonald. "Understanding Civil Law Scholarship in Quebec" (1985) 23 Osgoode Hall L.J. 573; S. Normand, "Une analyse quantitative de la doctrine en droit civil québécois" (1982) 23 C. de D. 1009; S. Normand. "Profil des périodiques juridiques québécois aux XIXe siècle" (1993) 34 C. de D. 153; S. Normand. "Un thème dominant de la pensée juridique traditionelle au Québec: La sauvegarde de l'intégrité du droit civil" (1987) 32 McGill L.J. 559. 
students, academics, lawyers and other readers; and that describes how all of these things have changed over time.

In contrast, in the United States there is a long and abundant tradition of scholarship about legal scholarship. In particular, American law reviews are filled with articles about what's wrong with student-edited law reviews, many of them expressing the view that the world would be better off without them. ${ }^{3}$ Three symposia on law reviews have been published in the past decade. ${ }^{4}$ The American debate has fixated for many years on the faculty-student tensions that arise from some of the distinctly absurd features of the dominant American model (that is, the Harvard model) of the university-based generalist law review. These features include the fact that beginners are responsible for editing a scholarly journal without substantial faculty involvement, often without reliance on peer review in the selection process. Another problem has been some student editors' tendency to approach their editorial assignments with immodest zeal, leading them to in essence rewrite manuscripts. These features have imbued the American literature on law reviews with tensions arising out of the power relations between faculty authors and student editors: law professors take out their frustrations on the lowly students, and the students keep publishing the flagellating articles. The tone of the debate in the United States was set by Fred Rodell's 1936 diatribe, "Goodbye to Law Reviews." He remarked that there are two things wrong with the writing in law reviews: "One is its style. The other is its content. That," he said, "about covers the ground."

Many of the issues that have featured prominently in the American debate are not relevant to our situation. For example, tension between students and faculty does not exist to anything like the same degree. Indeed, most university-affiliated Canadian law journals are cooperative enterprises involving faculty and students, that rely on peer review in selecting articles, and that take the view that there should be more text than footnotes, and that brilliant changes to accepted articles should be made sparingly and then only with the author's consent. We have achieved a more sensible division of labour between students, faculty, and authors.

So our issues are different. I want to make a modest contribution to our understanding of those issues by focusing on the situation of Canadian university-based generalist journals. The biggest challenge facing these journals is seeking to maintain high scholarly standards in an environment characterized by increasing competition for the best scholarly work. Book-length treatises aside, generalist journals were once the primary destination for legal scholars' work. Now a plethora of other publishing options and pressures may put generalist journals far down the list of preferred destinations, especially for the work of established, senior scholars. I do not want to echo some American commentators by

3 A thorough review of the literature can be found in B.J. Hibbitts, "Last Writes? Reassessing the Law Review in the Age of Cyberspace" (1996) 71 N.Y.U. L. Rev. 615. See also the symposia cited in infra note 4.

$4 \quad$ See "Special Issue: Law Review Conference" (1995) 47 Stan. L. Rev. 1117-1160; "A Symposium on Legal Scholarship" (1992) 63 U. Colo. L. Rev. 521-750; "Special Issue: Who Needs Law Reviews? Legal Scholarship in the Age of Cyberspace" (1996) 30 Akron L. Rev. 173-323. See also the forum on student-edited law reviews in (1986) $36 \mathrm{~J}$. Leg. Ed. 1-23.

F. Rodell, "Goodbye to Law Reviews" (1936) 23 Va. L. Rev. 38.

Ibid. at 38. 
suggesting that generalist law reviews should shut down entirely. I do not think we suffer from an overabundance of publishing venues for legal scholarship in Canada, if such a thing is possible. I do believe, however, that we have too many generalist law journals and too few scholarly law journals that specialize in particular interdisciplinary perspectives or methodologies. We would be better off if some university-based journals changed their names and objectives to move from a generalist to a specialist format.

\section{HiSTORY OF GENERALIST JOURNALS}

Let me briefly describe the history and evolution of Canadian university-based generalist journals. In this survey $I$ am leaving aside the various bar newsletters and journals like the Canadian Bar Review and the Revue du barreau. I am also leaving aside the law journals that publish student writing exclusively. ${ }^{7}$ And, for the moment, I am not speaking of journals that have a disciplinary or topical specialization.

\section{A. EARLiest Entrants}

There are now sixteen university-affiliated generalist law journals. Until 1934, there were none. A legal scholar in the 1920s or 1930s seeking to place an article could either send it abroad or to one of the Canadian bar reviews. The Canadian Bar Review commenced publication in 1923, after the publishers of the Canada Law Journal (18551922) and the Canada Law Times (1881-1922) agreed to fold and merge their publications in the new review. ${ }^{8}$ Additionally, in Quebec authors could consider sending commentaries to La Revue légale (1869-1942), the Revue du droit (1922-1939), the Revue du Barreau (1941-) or the Revue du notariat (1898-).

The first university-based generalist journal was the Alberta Law Quarterly, established in 1934 through the efforts of Professor M.M. Macintyre and the students at the University of Alberta School of Law. ${ }^{9}$ The Quarterly defined its mission in practical and regional terms. It was conceived as a

constructive programme in the interests of the profession... it will serve ... to link together the interests of the legal profession in the province and those of the School of Law at the University of Alberta. A professional school succeeds to the extent that it identifies itself in sympathy and aim with the highest interests of the practising members of the profession in the area which it serves."

The Quarterly lasted a decade until Dr. MacIntyre's departure from the university in 1944. After a hiatus of another decade, the Alberta Law Review rose from the ashes of the Quarterly in 1955."

There are now more than a half dozen Canadian law journals that fall in this category: Appeal (University of Victoria); Dalhousie Journal of Legal Studies; International Insights (Dalhousie); Revue d'études juridiques (Montréal); La Revue juridique (Laval); University of Toronto Faculty of Law Review; and the Osgoode Hall Student Law Review.

"Foreword" (1923) I Can. Bar Rev. I.

See Smith, supra note 1.

R.C. Wallace, "Foreword" (1934) I Alta. L.Q.

W.A. Stevenson, "The 'Emergence' of the Alberta Law Review" (1980) Twenty-Fifth Anniversary Issue Alta. L. Rev. 45. 
In 1935 the University of Toronto Law Journal ("U.T.L.J.") commenced publishing, becoming the second university-based generalist journal in Canada, well before the Law Society of Upper Canada accredited the university's Faculty of Law. W.P.M. Kennedy, the Dean of the law school, started the U.T.L.J. as a faculty-run journal. His broad vision and ambitions for legal scholarship, familiar to us now, were radical at the time. He and his colleagues did not view the law as an end in itself. Instead, they believed law needs to be examined in its social context, and its success measured by the promotion of social objectives. ${ }^{12}$ In the inaugural issue Dean Kennedy expressed the hope that the U.T.L.J. would "provide further incentive to legal scholarship" that would have the result of "deepening and purifying the social functions of law" and "elevating the standards of legal learning."

to produce a journal, learned and scientific. with high standards of scholarship and research which will be of interest to teachers and students of law, to members of the profession, to jurists, and to men of affairs.... We venture specially to hope that we may be able to do something to encourage legal scholarship in Canada, to foster a knowledge of the comparative laws of the British Empire. not merely as substantive or adjectival systems, but as expressions of organized community life, of ordered progress, and of social justice. ${ }^{14}$

As Dick Risk has noted, Kennedy's vision was a departure from the norm in Canadian legal publishing:

Other Canadian law journals had tended to treat law as an autonomous process and were dominated by the needs and interests of practising lawyers. In contrast, Kennedy's objectives stressed scholarship. not utility for practice, and suggested a substantially different way of thinking about law. ${ }^{\text {is }}$

"Caesar" Wright, who was editor of the Canadian Bar Review in the 1930s, bemoaned the arrival of the upstart U.T.L.J. in a letter to a colleague in 1936: "It seems rather a pity that there should be any competition in Canada for articles... and I am quite free to admit that The Canadian Bar Review committee is not a little perturbed at the eruption of the new Toronto journal into the legal review field in Canada." 16

\section{B. POST-WAR EXPLOSION}

Well, Caesar, things have gotten a lot worse. The number of university-based generalist law journals expanded steadily for a quarter century in the post-war period (see Appendix A and Chart 1, below). The University of New Brunswick Law Journal and the University of British Columbia Law Review began in the late 1940s. ${ }^{17}$ The 1950s brought five new

Risk, supra note $\mathbf{I}$ at 210.

W.P.M. Kennedy, "Foreword" (1935) I U.T.L.J. I at I-2.

Ibid. at 2.

Risk, supra note 1 at 194.

Cecil Augustus Wright to J.A. Corry, 12 February 1936, quoted in C.I. Kyer \& J.E. Bickenbach, The Fiercest Debate: Cecil A. Wright, the Benchers, and Legal Education in Ontario 1923-1957 (Toronto: University of Toronto Press, 1987) at 151.

The University of British Columbia Law Review commenced publication as UBC Legal Notes in 1949 before changing to its current name in 1959. 
university-based generalist law journals. ${ }^{18}$ Five more arrived on the scene in the $1960 \mathrm{~s}^{19}$ followed by another three in the early 1970 s. $^{20}$

And then growth abruptly stopped. The Windsor Review of Legal and Social Issues, which commenced publication in 1989, is the only new university-based generalist journal to have appeared since the Dalhousie Law Journal began publishing in 1973. It is debatable whether the Windsor Review qualifies as a generalist journal, since it aims to publish interdisciplinary perspectives on law as a vehicle for social change. ${ }^{21}$ The Windsor faculty council opted not to call the new journal the Windsor Law Review precisely because "it was strongly suggested that Canada's legal community did not require another traditional law review."22 The ranks of these journals dropped by one when the University of Western Ontario Law Review ceased publication in 1986. The steady growth in the number of university-based generalist journals that occurred from the late 1940 s to the early 1970 s reached a plateau thirty years ago. There were sixteen university-based generalist journals in 1973. There are sixteen now.

Chant 1: Growth of University-Basod Generaltst Journals

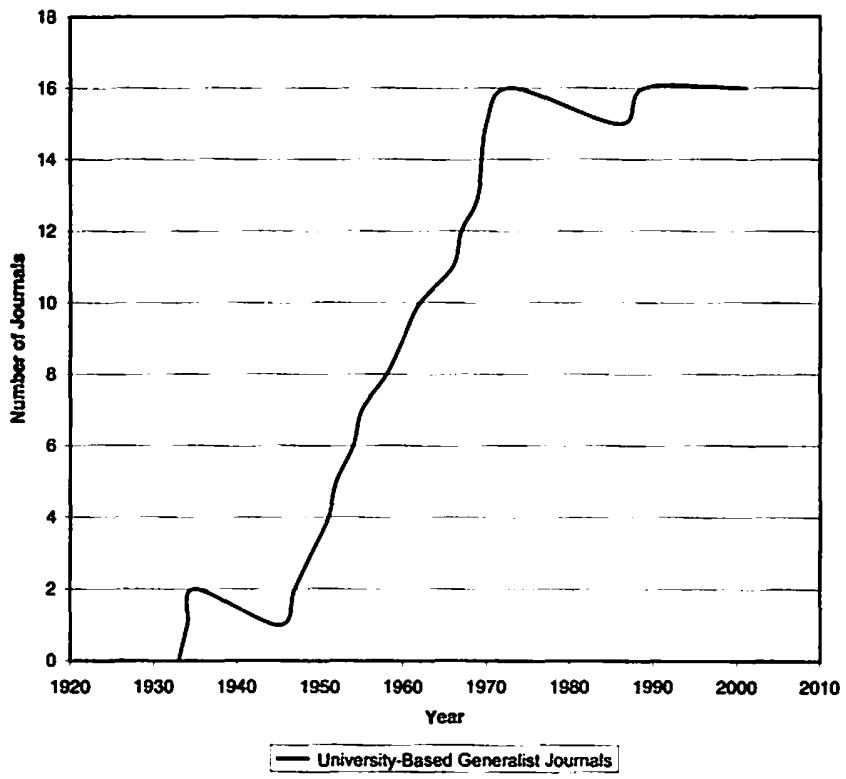

La Revue Juridique Themis (1951), the McGill Law Journal (1952), Les Cahiers de droit (Université Laval; 1954), the Alberia Law Review (1955), and the Osgoode Hall Law School Journal (1958) (now the Osgoode Hall Law Journal). The Osgoode Hall Law Journal did not become a universityaffiliated law journal until the Law Society of Upper Canada turned control of Osgoode Hall Law School over to York University in 1968.

Western Law Review (1960) (renamed the University of Western Ontario Law Review in 1976), Manitoba Law Journal (1962), Ottawa Law Review (1966), Saskatchewan Law Review (1967), and Queen's Intramural Law Journal (1969) (renamed the Queen's Law Journal in 1971). Revue de droit Université de Sherbrooke (1970), Revue générale de droir (1970; Université d'Ottawa) and Dalhousie Law Journal (1973).

" M.P. O'Reilly, "Introduction" (1989) I Windsor Rev. Leg. Soc. Iss. at i.

$3 \quad$ Ibid. 


\section{WHY UNIVERSITY-BASED GENERALIST JOURNALS?}

\section{A. INITIAL INTENTIONS}

With the exception of the U.T.L.J., the driving forces behind the establishment of the early university-based generalist journals were local and pedagogical. ${ }^{23}$ They were conceived as adjuncts of students' legal education. Participation in the journals would enrich students' learning while at law school. The main purpose of the journals was to give students encouragement in developing their legal research, writing, and editorial skills. ${ }^{24}$ The journals were more often than not student initiatives, edited by students for students. They published student papers exclusively or at least predominantly. Some were initially conceived as "in house" journals only. The work published in the journals had a practical focus: doctrinal analysis and descriptive notes on recent cases and legislation were the norm. Students and faculty members supported the establishment of new journals because they would provide a link between students' efforts and the needs of the bar, and they would advance the law schools' standing in the legal profession. ${ }^{25}$ A scholarly community autonomous from the bar was simply not in the students' minds as a constituency to be served in the early days of most university-based generalist journals. For example, the inaugural issue of the Osgoode Hall Law School Journal (as it was called in volumes 1 and 2) was published by the Students' Legal and Literary Society and contained the following editorial statement:

THE JOURNAL is a student undertaking, and we think, something of a pilot project in legal writing at Osgoode Hall Law School. THE JOURNAL is written and edited for the most part by students. Nevertheless, it is hoped that our efforts will find some favour beyond the student community among the members of the profession.

It is not our intention to limit or otherwise restrict the objectives that we have set for THE JOURNAL or to enunciate the editorial principles on which it is founded. Suffice it so say that THE JOURNAL

2" Local educational aims dominated at the origin of the Alberta Law Review, Les Cahiers de droit, the Maniroba Law School Journal, the McGill Law Journal, the Osgoode Hall Law School Journal, the Ottawa Law Review, the University of British Columbia Legal Notes, the University of New Brunswick Law Journal, the Western Law Review, the Windsor Review of Legal and Social Issues, and Thémis (Université de Montréal).

is See, e.g., "Editor's Page" (1966) I Ottawa L. Rev. v at vi ("We hope that with the establishment of the Review, law students, practitioners, judges and scholars will recognize that a student who has served on the board has learned skills and techniques of disciplined research and writing that may determine success in any branch of the legal profession."); "Editor's Note" (1960) I West. L. Rev. ii ("The object of the Review is to stimulate legal research and writing in the law scloool, and to provide special opportunities for training in the collation and analysis of legal materials, with accuracy and relevance... the Review is regarded as an internal affair, written by students for student purposes, circulation being confined to the school."); "Editorial" (1949-52) 1 U.B.C.Legal. N. at 2 ("We believe that students should be encouraged to undertake research in connection with, or apart from, their particular law courses, primarily as an incident to the attainment of scholarship but also as a means of increasing their interest in the Faculty... It is hoped that this present venture will meet a favourable response from the student body and from the profession in the Province and clsewhere").

:s See, e.g., L. Bolduc, "Présentation" (1954) I C. de D. 6: "Nous les croyons propres à développer chez les étudiants actuels et chez leurs successeurs un esprit de recherche dans le domaine juridique contribuant à maintenir haut le prestige de l'université à laquelle nous appartenons." 
hopes to encourage student writing and to be the catalyst in a programme of legal writing which can be a rewarding educational experience."

\section{B. Change in Function}

The transformation of university-based generalist journals from publications written by and for students to more scholarly journals occurred quickly. The proportion of the journals' pages occupied by student writing dwindled rapidly as the ranks of full-time law professors swelled, and legal scholarship started to come of age as a distinct academic discipline. By the late 1960s and early 1970s, the generalist journals had become significant venues for legal scholarship and they had reformulated their aims and procedures to set high scholarly standards. The journals that were initiated and run exclusively by students became cooperative faculty-student enterprises. The following editorial from the Osgoode Hall Law Journal in 1984 expresses the transformation in organizational structures and scholarly aims that many genẹralist journals experienced:

This is the first issue of the Journal to be published as a joint laculty-student enterprise. This has led to considerable change in the organization and presentation of the Journal. As well as improving its appearance, the Editorial Board hopes to change its substantive locus and reach. Adopting a more expansive understanding of 'legal scholarship,' the policy will be to publish papers aboul law as much as of law. Although traditional forms of scholarship will be retained and encouraged, a greater range and style of writing will be actively pursued and published. The ambition is to make the Journal into a forum for the exchange and expression of new ideas about law in all its manifestations and meanings. both theoretical and practical. The criterion of publication will be quality and originality, not orientation or orthodoxy."7

All of the existing sixteen university-based generalist law journals now involve some degree of faculty participation. Five have a board of editors composed exclusively of faculty, ${ }^{28}$ one has a joint student-faculty board,,$^{29}$ two have a student board headed by a faculty editor-in-chief, ${ }^{30}$ and eight have student boards that rely to varying degrees on faculty advisors. ${ }^{31}$

(1958) I Osgoode Hall L. Sch. J. at unnumbered front page.

"Editorial" (1984) 22 Osgoode Hall L.J. at unnumbered front page [emphasis in original]. The five journals with faculty editorial boards are University of Toronto Law Journal, Les Cahiers de droit, Revue générale de droit, Revue de Droit Université de Sherbrooke, and Thémis. Dalhousie Law Journal has a joint student-faculty board of editors.

Osgoode Hall Law Journal and Saskatchewan Law Review have student boards with a faculty member as editor-in-chief.

The journals with student boards advised by faculty members are the Alherla Law Review. the McGill Law Journal, the Ottawa Law Review, the Queen's Law Journal, the University of British Columbia Law Review, the University of New Brunswick Law Journal, the Manitoba Law Journal, and the Windsor Review of Social and Legal Issues. 


\section{The Emergence of SPECialist Journals}

While the period of growth of generalist journals is behind us, that is not the case for Canadian law journals generally. In the last thirty years we have witnessed an explosion in specialist journals that has coincided precisely with the levelling off in the growth of generalist journals. Since law is now subject to analysis from many disciplinary perspectives, any attempt to count all of the specialist legal journals will rely to some extent on arbitrary criteria. In my tally, I have tried to isolate the journals that focus on legal issues and are significant venues for legal scholarship. However one defines them, the trend is easily identifiable.

Chart 2: Growth of Speciallst Joumals

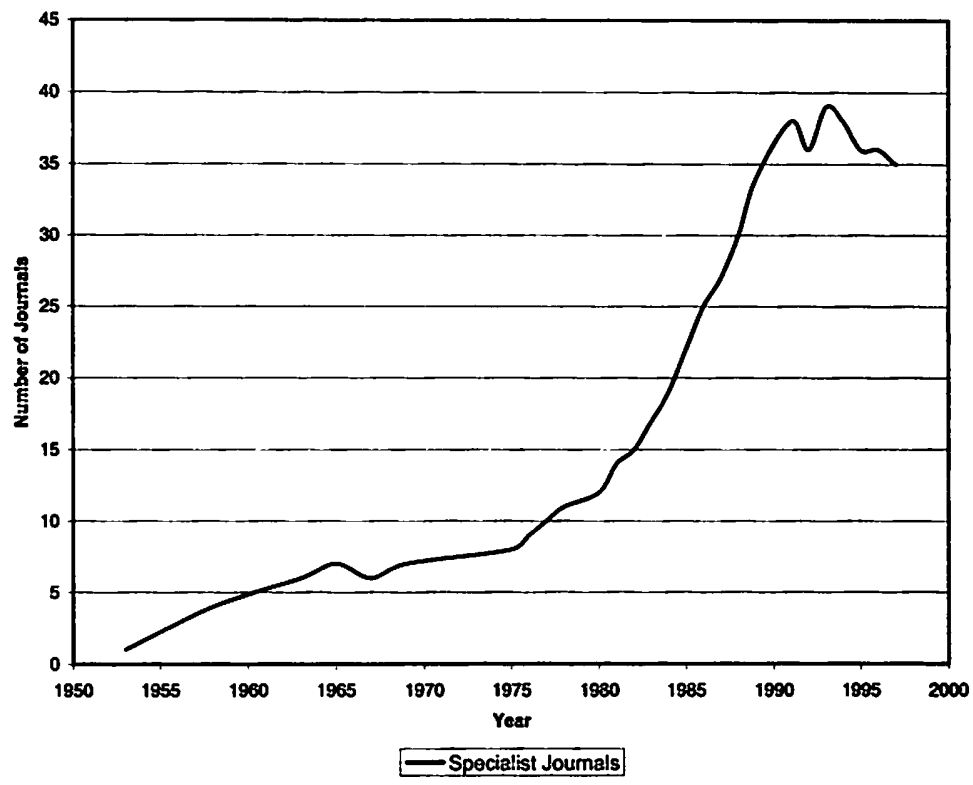

There were no specialist journals until the 1950s. The Criminal Law Quarterly, one of the oldest, commenced publishing in 1958. By 1970, there were seven specialist journals; by 1980, a dozen. The most dramatic growth occurred in the 1980s: twenty-four new specialist journals appeared, although nine of them ceased publication in the 1990s. There are now, and have been since the early 1990s, about forty specialist law journals published in Canada, more than twice the number of generalist journals. The rate of growth of specialist journals levelled off in the 1990s, reproducing two decades later the pattern followed by generalist journals in the early 1970s. It is likely, however, that the number of specialist journals will continue to expand in the future, and that the lull of the past decade has more to do with the financial difficulties of launching new journals when public funding is scarce and the library and marketing budgets of universities, law offices, and other institutions are under pressure. 
Chart 3: Comparison of Growth of Speclallst and University-Based Generallst Joumals

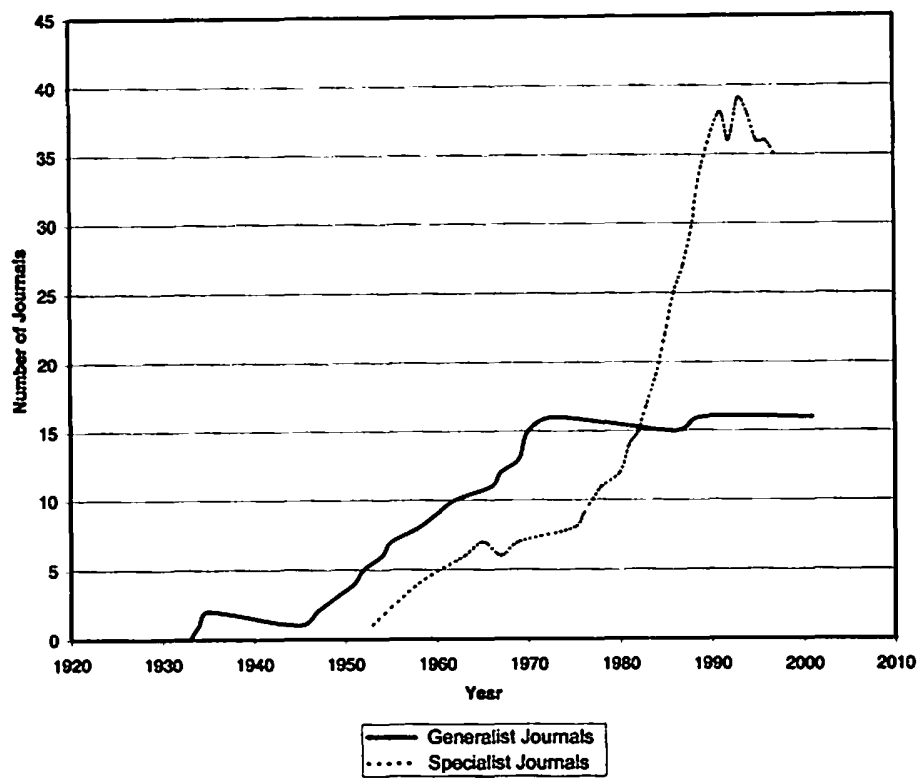

The vast majority of the new specialist journals are topical, many of them produced by commercial publishers aimed at a market composed primarily of non-academic lawyers. Many of these journals are not competitors with the university-based scholarly journals - they publish articles of practical importance for their immediate audience; whereas most of the university-based law journals seek to make more enduring contributions to legal knowledge. A significant minority of the specialist journals follow similar scholarly standards as the university-based generalist journals and compete with them for the same articles. ${ }^{32}$ Most of the topical journals do not aspire to high scholarly standards. They seek to provide marketable information to lawyers.

There is a striking absence of any Canadian topical journals in some areas where there is an abundance of scholarship and public interest. For example, there are no Canadian journals that specialize in Aboriginal legal issues. And there are remarkably few Canadian law journals that have an interdisciplinary or methodological specialization. Only four fall in this category. ${ }^{33}$ This is the area ripest for growth in the world of Canadian legal scholarly periodicals. There is a real need for Canadian journals specializing in legal

32 Examples of specialist journals that apply scholarly standards similar to the university-based generalist journals are the National Journal of Constitutional Law, the Criminal Law Quarterly, the Canadian Journal of Family Law, the Canadian Journal of Women and the Law, the Canadian Journal of Law and Society, the Canadian Journal of Law and Jurisprudence, the Health Law Journal, the Supreme Court Law Review, and the Review of Constitutional Studies.

" The journals with a disciplinary or methodological specialization are the Canadian Journal of Women and the Law (feminist legal theory), the Canadian Journal of Law and Society (sociology of law), the Canadian Journal of Law and Jurisprudence (philosophy of law), and the Canadian Journal of Criminology. 
history, law and economics, critical race theory, queer legal theory, comparative law, legal pluralism, and other approaches to legal analysis.

What accounts for the unpopularity of the generalist format since the early 1970s, and the dramatic growth in the number of specialist journals? One obvious explanation is that the growth of generalist journals corresponded to the growth in the number and size of Canadian law schools. But this cannot provide a full answer. Some of the newer law schools - Calgary, Victoria, Université du Québec à Montréal, and Moncton - have not found it necessary to inflict new generalist law journals on us. Moreover, generalist journals stopped appearing even though universities were hiring more full-time legal academics. From 1971 to 1986, the number of full-time law professors increased from 389 to $690{ }^{34}$ a jump of more than 75 percent. Yet there has been no growth in generalist journals since 1973.

Another part of the explanation may lie in a shift from public to private sources of sustenance for legal journals. If the market for advertising and subscriptions plays a large role in dictating which journals are launched and which survive, scholarly journals will not prosper in a country of our size. Topical journals aimed at legal practitioners have a better chance of success. The realities of the market help explain the proliferation of commercial, for-profit topical journals in the 1980s, as well as the demise of many of them in the 1990s.

The shift from generalist to specialist journals is also a reflection of profound changes in the nature of legal scholarship, legal institutions, and legal cultures that have occurred since the late 1960s, the end of the era of growth of university-based generalist journals in Canada. As legal scholarship has matured, the local, practical, and educational mission of many law journals has been eclipsed by the need to disseminate the growing body of substantial legal scholarship produced by full-time academics. The complexity and quantity of legal knowledge has steadily expanded. Other pressures are fracturing the worlds of legal practice and scholarship. Lawyers, scholars, and students can no longer cling to the absurd pretence of being expert in all things legal. We must specialize. As Harry Arthurs has pointed out, lawyers and legal scholars are divided "into subprofessions clustered around differing bodies of knowledge ... the notion of a single unified legal profession is becoming increasingly less plausible." ${ }^{35}$ As a result, apart from the editors responsible for production, nobody in his or her right mind reads a generalist law journal cover to cover. As Alan Mewett commented in a 1955 article:

One of the basic mistakes which the law review makes is in its failure to be designed for any audience at all. It presents a most unfortunate mass of ill-assorted, heterogeneous articles, connected only by the at 303 .

is H.W. Arthurs, "A Lot of Knowledge is a Dangerous Thing; Will the Legal Profession Survive the Knowledge Explosion?" (1995) 18 Dal. L.J. 295 at 309. See also H.W. Arthurs. "The Political Economy of Canadian Legal Education" (1998) 25 J. L. \& Soc. 14: H.W. Arthurs, "Globalization of the Mind: Canadian Elites and the Restructuring of Legal Fields" (1997) 12 Can. J. L. \& Soc. 219. 
fact that they appear in the same review. In its understandable desire for continuity of form, the law review appears to have completely sacrificed continuity of substance."

Developments in the nature of legal knowledge since 1955 make Mewett's trenchant observations even more $a$ propos now. The barriers that have separated legal research from other disciplines continue to crumble. Respected legal scholarship is increasingly interdisciplinary. Nor is scholarly activity bounded geographically. Scholars' collegial ties, interests and audiences transcend national boundaries. Especially compared to the simpler dilemmas of scholars outside Quebec seeking to place a paper in a Canadian law journal in the 1930s - "do I go with the Canadian Bar Review or the University of Toronto Law Journal?" - scholars now, happily, have a bewildering array of choices. They are increasingly publishing in journals outside of Canada and in journals specifically targeted to global audiences. Moreover, our best scholars are devoting more time to publishing books or monographs than their predecessors. These trends are likely to continue in the years ahead.

\section{Why RETAIN a GeNERALIST Format?}

In light of these larger trends in the nature of legal scholarship and scholarly communities, it is clear that the golden age of the generalist legal journal is well behind us. These journals can and will survive, but it is worth asking whether the original reasons for adopting the generalist format continue to be compelling. If not, then there are good reasons to contemplate change. Even the best of the Canadian generalist journals find that the number of high-quality submissions landing on their desks is depressingly low. ${ }^{37}$ Editorial boards know that they can ill afford to sit and wait for unsolicited manuscripts to arrive in the mail. Quality will suffer without a proactive approach. Editors have to beat the bushes, berate colleagues, plan symposia and theme issues, or resort to other tactics to drum up submissions and fill issues. Flyers and e-mail requests inviting submissions are commonplace, even though editors know that they may send a signal of desperation that risks undermining their efforts to capture articles that might not otherwise come their way. The need for regular theme issues has meant that a number of generalist law journals have become specialist journals in all but name, at least part of the time. The Alberla Law Review, for example, by publishing its annual petroleum law supplement, also functions as the equivalent of a Canadian Petroleum Law Journal.

One reason that generalist journals have not changed is that they have served well the pedagogical and promotional goals of law schools and law students. In addition, a number of university-based journals are tied to a generalist format by their connections to provincial bar associations or the need to provide a forum for the exploration of regional issues. These local and institutional pressures have prevailed over a more comprehensive and potentially more rational approach to assessing the role of university-based law journals. Unfortunately we have lacked organization - an association of Canadian law

A.W. Mewett, "Reviewing the Law Reviews:" (1955) 8 J. Leg. Ed. 188 at 188.

As one editor of the McGill Law Journal put it, "A greater challenge for the Journal is the current trend towards specialization. The increasing number of specialized law journals has somewhat eroded the amount of submissions we receive as a general law journal." J. Lackman, "Afterword: Forty Years Later" (1995) 40 McGill L.J. 1025 at 1026. 
journals which could play a role in planning the collective evolution of Canadian law journals.

From the point of view of enhancing Canadian legal scholarship generally, there are a number of advantages that specialist journals offer. They more accurately convey their mission and target their market for readers and authors. The board of editors has more opportunity to develop and draw upon real expertise. They can more readily serve a national and international audience. The quality of the scholarship that fills their pages could be significantly enhanced.

For these reasons, one future path that needs to be explored is the possibility of some generalist journals reinventing themselves as specialist journals. A national association and a coordinated effort could best accomplish this goal. Apparently, the "First National Conference of Student Law Reviews" was held at Osgoode Hall in Toronto in February 1959 , right in the middle of the period of growth of university-based generalist journals. ${ }^{38}$ Generalist journals inhabit a very different scholarly universe now. Much could be gained if a forum were established in which those journals could discuss their collective future. At such a forum, a great deal could be accomplished by identifying common challenges and sharing knowledge, experiences, and strategies for enhancing financial health and scholarly quality. A great deal of this information remains stored "in house," in the files and institutional memories at particular law schools. This lack of informational sharing is a problem that is partly attributable to competitive isolation and to the constant turnover in the membership of university-based generalist journals' student editorial boards. ${ }^{39}$

\section{CONClusion}

As generalist journals engage in soul-searching, either collectively or individually, no doubt some will stand by their choice to avoid committing to greater specialization. The bar reviews are not likely to change. University-based journals with close ties to the bar - like the Alberta Law Review and the Saskatchewan Law Review - could only shed their generalist missions if they were willing to lose the support and patronage of the provincial bar associations. While financial considerations may lean heavily against it, specialization is a course worth contemplating since the needs and interests of practicing lawyers do not always coincide comfortably with work produced by a journal with high

This conference is briefly mentioned in "Editorial" (1959) I U.B.C. L. Rev. The editors' selfconfident note reflects the upward trajectory in numbers and scholarly standards enjoyed by generalist law journals at the time: "It was a pleasure to attend this conference and learn that publications such as ours are recognized nationally as having a definite function in encouraging legal writing and research as well as supplying fresh and provocative articles for both the student and the profession." Since this article was written a meeting of Canadian law journals was convened in Saskatoon on August 3, 2001. Representatives of four generalist journals (Alberta, British Columbia, Saskatchewan and Osgoode) participated in the meeting and discussed issues of administration, multiple submissions, consistency of style, electronic publication, financing, and increasing communication and networking among the journals. The participants resolved to form the Canadian Association of Law Journals and to hold a second meeting in Toronto in 2002. Meetings of the new association will provide a good forum for considering the possibility of coordinating efforts to reinvent the landscape of Canadian law journals. 
scholarly ambitions. ${ }^{40}$ Many members of the profession have limited interest in legal theory and empirical research. There is much to be said for having bar journals like the Law Society of Upper Canada Gazette or the Advocate in British Columbia coexist with university-based scholarly journals in each province.

The need for generalist law journals to play a role in promoting distinct regional legal cultures is also a counterbalance to pressures towards specialization. As Dale Gibson commented on introducing the first issue of the Manitoba Law Journal:

[The Journal] should be devoted chiefly, though certainly not exclusively, to the work of Manitoba writers, and to material having a peculiar significance within the province. To do otherwise would be to engage in fruitless competition with the already too numerous periodicals whose chief appeal is national or international. It is hoped that the Journal can be regional without being provincial."

While the Manitoba Law Journal and other generalist journals have since expanded their horizons, regional considerations no doubt will continue to weigh heavily for the six generalist journals that are the only ones in their respective provinces. ${ }^{42}$ This will also be true for the collection of generalist journals in Quebec that play a special role as guardians of the civil law tradition. ${ }^{43}$ And so long as there is a Harvard Law Review, there will be a University of Toronto Law Journal. In the future, assuming resources become available, law schools are likely to supplement rather than replace their existing generalist journals with new specialist journals, following the example set by the University of Alberta, where in addition to the Alberta Law Review, two health journals and two constitutional journals are published by the Health Law Institute and the Centre for Constitutional Studies respectively. This too has been the pattern in the United States where it seems a law school with any aspirations to high standing now must have at least a handful of new specialist law reviews.

Despite these countervailing factors, the pressures towards specialization and the challenges posed by the fragmentation of legal knowledge to the vitality of generalist journals cannot be ignored. It is worth contemplating putting in place a forum where these issues can be debated collectively and a coordinated plan perhaps developed. It may be that if, say, the Manitoba Law Journal became the Canadian Journal of Legal History, or the U.B.C. Law Review became the Canadian Journal of Asia-Pacific Studies, or the Queen's Law Journal became the Canadian Journal of Law, Gender, and Sexuality, or the McGill Law Journal became the Canadian Journal of Comparative Law, we would all be better off.

For an example of an attempt to navigate the tensions that can arise in attempting to serve academics and practicing lawyers, see C. Hunt, "Editorial" (1971-72) 36 Sask. L. Rev. I.

" R.D. Gibson, "Preface" (1962-5) I Man. L. Sch. J. I.

\$2 The University of British Columbia Law Review, the Alberta Law Review, the Saskatchewan Law Review, the Manitoba Law Journal, the University of New Brunswick Law Journal. and the Dalhousie Law Journal are the only generalist journals in their respective provinces. 


\section{APPENDIX A: UNIVERSITY-BASED GENERALIST JOURNALS}

The list does not include bar reviews or journals that publish only student-authored articles. The journals are listed chronologically according to date of first publication.

$\begin{array}{ll}\text { 1. } & \text { Alberta Law Quarterly } \\ \text { 2. } & \text { University of Toronto Law Journal } \\ 3 . & \text { University of New Brunswick Law Journal } \\ \text { 4. } & \text { University of British Columbia Law Review } \\ \text { 5. } & \text { Thémis (Université de Montréal) } \\ \text { 6. } & \text { McGill Law Journal } \\ 7 . & \text { Les Cahiers de Droit (Université Laval) } \\ \text { 8. } & \text { Alberta Law Review } \\ 9 . & \text { Osgoode Hall Law Journal } \\ \text { 10. } & \text { University of Western Ontario Law Review } \\ 11 . & \text { Manitoba Law Journal } \\ \text { 12 } & \text { Ottawa Law Review } \\ 13 . & \text { Saskatchewan Law Review } \\ \text { 14 } & \text { Queen's Law Journal } \\ \text { 15. } & \text { Revue de Droit Université de Sherbrooke } \\ \text { 16. } & \text { Revue Générale de Droit (University of Ottawa) } \\ \text { 17. } & \text { Dalhousie Law Journal } \\ \text { 18. } & \text { Windsor Review of Legal and Social Issues }\end{array}$

1934 - 1945
1935 - present
1947 - present
1949 - present
1951 - present
1952 - present
1954 - present
1955 - present
1958 - present
1960 - 1986
1962 - present
1966 - present
1967 - present
1969 - present
1970 - present
1970 - present
1973 - present
1989 - present

\section{APPENDIX B: SPECIALIST JOURNALS}

The following list of law journals, that specialize by topic or discipline, is drawn from the holdings of the law library at York University. I have attempted to list all journals that contained significant legal analysis. No doubt a more thorough search would yield a lengthier list. The journals are listed chronologically according to date of first publication.

1. Canadian Tax Journal

2. Canadian Journal of Criminology

3. Canadian Public Administration

4. Criminal Law Quarterly

5. Canadian Yearbook of International Law

6. Colloque International de Droit Comparé

7. Yearbook of Air \& Space Law

8. Canadian Communications Law Review

9. Estates, Trusts \& Pensions Journal

10. Canadian Business Law Journal

11. Canadian Public Policy

12. Annals of Air and Space Law

13. Advocates' Quarterly

14. Legal Medical Quarterly

15. Canadian Journal of Family Law

1953 - present
1958 - present
1958 - present
1958 - present
1963 - present
1963 - 1975
1965 - 1967
1969 - 1973
1973 - present
1975 - present
1975 - present
1976 - present
1977 - present
1977 - present
1978 - present 
16. Supreme Court Law Review

1980 - present

17. Ombudsman Journal

$1981-1994$

18. Windsor Yearbook of Access to Justice

1981 - present

19. Annual Review of Criminal Law

1982 - present

20. Canadian Human Rights Yearbook

$1983-1992$

21. Canadian Journal of Insurance Law

1983 - present

22. Canadian Intellectual Property Review

1984 - present

23. Intellectual Property Journal

24. Administrative Law Journal

25. Canadian Journal of Women and the Law

1984 - present

$1985-1990$

26. Journal of Law and Social Policy

1985 - present

1985 - present

27. Banking \& Finance Law Review

1986 - present

28. Canadian Family Law Quarterly

1986 - present

29. Canadian Journal of Law and Society

30. Canada-U.S. Business Law Review

1986 - present

$1987-1992$

31. Review of International Business Law

$1987-1989$

32. Canadian Journal of Administrative Law \& Practice

1988 - present

33. Canadian Journal of Law and Jurisprudence

1988 - present

34. Education and Law Journal

1988 - present

35. Canadian Insurance Law Review

$1989-1996$

36. Canadian International Trade Journal

$1989-1997$

37. Constitutional Forum

38 Journal of Human Justice

1989 - present

$1989-1995$

$1989-1996$

39. Journal of Motor Vehicle Law

$1990-1995$

40. Media \& Communications Law Review

1991 - present

1991 - present

42. Journal of Environmental Law and Practice

1991 - present

43. Labour Arbitration Yearbook

1991 - present

44. National Journal of Constitutional Law

45. Canadian Labour and Employment Law Journal

1993 - present

46. Health Law Journal

47. Review of Constitutional Studies

1993 - present

1993 - present

48. Canadian Criminal Law Review

1996 - present

49. Canadian Journal of International Business Law \& Policy

1996 - present 